\title{
PERAN TENAGA KERJA WANITA DALAM USAHATANI HORTIKULTURA DI KELURAHAN WAILAN, TOMOHON UTARA, KOTA TOMOHON
}

\author{
Marlina Damatun \\ Ventje V. Rantung \\ Melsje Y. Memah
}

\begin{abstract}
This study aims to determine of women workers in the horticultural farm in the Village Wailan. The research was conducted in November 2016 to April 2017, from preparation to preparation of the report. The data used primary data and secondary data. This research was conducted with a purposive sampling technique, the number of samples taken by 30 respondents. The data were analyzed descriptively presented in table form. The results showed that the working hours of women at Harvest activity of 2.56 hours / day, planting 1.7 hours / day, tillage 1.66 hours / day, weeding 0.46 hours / day, nursery 0.4 hours / day, fertilization 0.26 hours / day and control of pests and diseases 0 hours / day.
\end{abstract}

Key words: role, women's labor, horticulture farming, Wailan Village, Tomohon City

\begin{abstract}
ABSTRAK
Penelitian ini bertujuan untuk mengetahui peran tenaga kerja wanita dalam usahatani hortikultura di Kelurahan Wailan. Penelitian ini dilaksanakan pada Bulan November 2016 hingga April 2017, mulai dari persiapan sampai penyusunan laporan. Data yang digunakan data primer dan data sekunder. Penelitian ini dilakukan dengan teknik purposive sampling, dengan jumlah sampel yang diambil sebanyak 30 responden. Analisis data dilakukan secara deskriptif yang disajikan dalam bentuk tabel. Hasil penelitian menunjukan bahwa curahan waktu kerja wanita pada kegiatan Panen 2,86 jam/hari, penanaman $1,8 \mathrm{jam} / \mathrm{hari}$, pengolahan tanah $1,7 \mathrm{jam} / \mathrm{hari}$, penyiangan $0,46 \mathrm{jam} / \mathrm{hari}$, pembibitan $0,4 \mathrm{jam} / \mathrm{hari}$, pemupukan $0,26 \mathrm{jam} / \mathrm{hari}$ dan pengendalian hama dan penyakit $0 \mathrm{jam} / \mathrm{hari}$.
\end{abstract}

Kata kunci: peran, tenaga kerja perempuan, pertanian hortikultura, Desa Wailan, Kota Tomohon

\section{PENDAHULUAN}

\section{Latar Belakang}

$\begin{array}{ccc}\text { Sebagai } & \text { negara } & \text { agraris, pemerintah } \\ \text { Indonesia } & \text { masih } & \text { menitik-beratkan }\end{array}$ pembangunannya pada sektor pertanian (Rian, 2014). Indonesia merupakan Negara yang memiliki sumber daya alam yang belimpah dan beraneka ragam. Seperti diketahui Sektor pertanian dalam perannya sebagai penyedia bahan pangan yang merupakan salah satu kebutuhan pokok manusia, sektor pertanian juga berperan dalam penghasil devisa negara melalui ekspor dan merupakan salah satu sektor pemberi lapangan kerja.

Di Indonesia sebagian besar penduduknya tinggal di pedesaan, dan Sektor pertanian telah menjadi sektor paling utama dalam penyerapan tenaga kerja. Tenaga kerja merupakan salah satu aspek paling penting dalam berbicara tentang usahatani. Dalam usahatani dikenal ada tiga jenis tenaga kerja yaitu tenaga kerja manusia, tenaga kerja hewan, dan tenaga kerja mesin/mekanis. Sedangkan tenaga kerja manusia terbagi dalam tiga jenis pula yaitu tenaga kerja pria, tenaga kerja wanita dan tenaga kerja anak.

Setelah adanya perkembangan peran dan posisi kaum wanita yang sejak dahulu telah menempatkan wanita sebagai mitra yang sejajar dengan kaum pria, maka fenomena wanita bekerja pada sektor pertanian bagi masyarakat bukanlah hal yang baru dan bukanlah hal yang tidak mungkin terjadi. Karena mayoritas mata pencaharian penduduk desa adalah bertani maka kebanyakan wanita yang ikut bekerja dalam 
membantu perekonomian keluarga pada akhirnya bekerja pula di bidang pertanian.

Peran tenaga kerja wanita dalam usahatani hortikultura cukup besar, mereka bekerja dalam beberapa kegiatan usahatani produksi serta pasca panen. Dalam dunia pertanian, wanita tidak hanya berperan sebagai ibu rumah tangga saja, namun banyak ditemui pula wanita yang berperan atau secara langsung memberi kontribusi nyata terhadap usahatani yang diusahakan oleh keluarga itu sendiri. Kegiatan usahatani yang dilakukan wanita tani dipengaruhi oleh curahan waktu kerja. Curahan waktu kerja wanita tani dalam kegiatan yang produktif banyak tergantung pada faktor sosial ekonomi dan keadaan keluarganya. Faktor-faktor sosial ekonomi yang berpengaruh pada curahan waktu kerja wanita tani adalah tingkat umur, jumlah tanggungan keluarga, tingkat upah, luas lahan, status perkawinan, tingkat pendidikan, dan tingkat pengalaman (Novita, 2012). Tanaman hortikultura merupakan salah satu komoditi pertanian yang banyak diusahakan oleh sebagian petani. Tanaman hortikultura sangat bermanfaat bagi manusia dan lingkungan sekitar yaitu sebagai salah satu sumber pangan dan gizi yang dibutuhkan manusia serta dapat dijadikan usaha guna menambah pendapatan ekonomi keluarga. Kelurahan Wailan berada di bagian Utara Tomohon Kota Tomohon dengan luas wilayah Kelurahan Wailan adalah sekitar 450 Ha dengan jumlah penduduk 3.199 jiwa yang sebagian besar penduduknya adalah berprofesi sebagai petani. Dari total jumlah penduduk di Kelurahan Wailan terdapat 205 petani wanita. Di Kelurahan Wailan ada 2 macam jenis usahatani yang di usahakan yaitu padi sawah dan hortikultura. Tanaman hortikultura merupakan salah satu komoditi pertanian yang banyak diusahakan oleh sebagian besar petani di kelurahan wailan. Usahatani hortikultura sangat cocok di usahakan di kelurahan wailan karena didukung oleh letak geografis, tanaman hortikultura yang ditanam oleh petani di Kelurahan Wailan yaitu tanaman sayuran yang terdiri dari tanaman Buncis, Caisin, Pitsai, Kol, dan Daun bawang.

\section{Hortikultura}

Hortikultura (horticulture) berasal dari bahasa latin, yaitu hortus yang berarti kebun dan colere yang berarti menumbuhkan (terutama sekali mikroorganism) pada suatu medium buatan. Secara harafiah, hortikultura berarti ilmu yang mempelajari pembudidayaan tanaman kebun. Akan tetapi, pada umumnya para pakar mendefinisikan hortikultura sebagai ilmu yang mempelajari budidaya tanaman sayuran, buah-buahan, bunga-bungaan atau tanaman hias (Zulkarnain, 2014). Tanaman hortikultura mencakup jumlah spesies yang sangat banyak dan beragam. Jumlah spesies yang sudah dibudidayakan diperkirakan ada sekitar 323 spesies. Di antaranya 80 spesies tanaman sayuran, 60 spesies tanaman buahbuahan, 117 spesies tanaman hias dan 66 spesies tanaman biofarmaka. Di tinjau dari segi kesehatan, tanaman sayuran memainkan peran yang sangat penting karena sayuran merupakan sumber vitamin, mineral, serat dan juga sebagai sumber bahan-bahan yang dapat menyembuhkan penyakit (Wijaya, 2012).

Pengembangan hortikultura di Indonesia pada umumnya masih dalam skala perkebunan rakyat yang tumbuh dan dipelihara secara alami dan tradisional, sedangkan jenis komoditas hortikultura yang diusahakan masih terbatas. Indonesia merupakan Negara tropis dengan wilayah cukup luas, dengan variasi agroklimat yang tinggi, merupakan daerah yang potensial bagi pengembangan hortikultura baik untuk tanaman dataran rendah maupun dataran tinggi. Pada umumnya budidaya hortikultura diusahakan lebih intensif dibandingkan dengan budidaya tanaman lainnya (Ginting, 2015).

\section{Usahatani}

Mifta (2000) usahatani adalah kegiatan ekonomi dimana mempelajari bagaimana mengalokasi sumber daya usahatani yang terbatas untuk memenuhi kebutuhan dan kehendak manusia yang tidak terbatas.

Ilmu usahatani juga biasanya diartikan sebagai ilmu yang mempelajari bagaimana seseorang mengalokasikan sumberdaya yang ada secara efektif untuk tujuan memperoleh keuntungan yang tinggi pada waktu tertentu (Soekartawi, 1995). Usahatani petani atau usahatani keluarga dalam hakekatnya dapat digolongkan menjadi: usahatani dalam dasarnya ditunjukan untuk memprodusir bahan-bahan yang langsung diperlukan oleh keluarga petani. Karenanya maka pada umumnya jenis-jenis 
tanaman yang diusahakan adalah, jenis-jenis tanaman makanan. Usaha terutama ditunjukan untuk memenuhi kebutuhan hidup sehari-hari, usaha sifatnya "swasembada" dalam keperluan pokok dari keluarga petani. Karena itu maka usahatani yang demikian sifatnya itu disebut dengan nama (subsistence farming) "usahatani swasembada" (Tohir, 1991). Ada 4 unsur utama yang menjadi pembentuk dalam setiap kegiatan usahatani (Hernanto, 1993 dalam Pelealu, 2005), termasuk dalam usahatani hortikultura. Empat unsur tersebut antara lain adalah :

\section{Tanah}

Tanah merupakan merupakan salah satu faktor pembentuk usahatani karena tanah merupakan tempat atau ruang bagi seluruh kehidupan dimuka bumi baik manusia, hewan dan juga tumbuh-tumbuhan/tanaman.

\section{Tenaga kerja}

Ada tiga jenis tenaga kerja yang dikenal dalam usahatani yakni tenaga kerja manusia, tenaga kerja hewan, tenaga kerja mesin/mekanis. Tenaga kerja manusia dibedakan atas tiga jenis :

- Tenaga kerja pria

- Tenaga kerja wanita

- Tenaga kerja anak

\section{Modal}

Modal merupakan salah satu unsur yang paling penting dalam mendukung suatu keberhasilan usahatani. Tanpa adanya modal maka besar kemungkinan suatu usahatani tidak akan terlaksana.

Modal yang dimaksud dalam usahatani adalah:

- Tanah

- Bangunan (gedung, kandang, lantai jemur, pabrik dll)

- Alat-alat pertanian (traktor, cangkul, sprayer, parang, dll)

- Tanaman

- Bahan-bahan pertanian (pupuk, bibit, pestisida)

Berdasarkan sifatnya modal usahatani dapat dibagi menjadi 2 jenis yaitu :

a. Modal tetap (fixed capital) yaitu modal yang dapat digunakan berulang-ulang kali dalam jangka waktu yang panjang seperti bangunan dan tanah.

b. Modal bergerak (variable capital) yaitu meliputi alat-alat pertanian, uang tunai, piutang bank, tanaman. Jenis modal ini tidak akan habis dalam satu periode proses produksi.

\section{Pengolahan (manajemen)}

Pengolahan usahatani adalah kemampuan usahatani dalam menentukan, mengorganisir dan mengkoordinasi faktorfaktor produksi yang dikuasainya sebaikbaiknya dan mampu memberikan produksi pertanian sebagaimana yang diharapkan. Ukuran dari hasil pengelolahan itu adalah produktivitas dari setiap faktor yang mampu berproduksi dari usahanya. Inti dari semua itu adalah manusia yaitu dengan akal budinya akan menumbuhkan kehendak berpikir konsepsional.

\section{Konsep Tenaga Kerja}

UU No. 13 Tahun 2003 tentang ketenagakerjaan, pengertian tenaga kerja adalah setiap orang yang mampu melakukan pekerjaan guna menghasilkan barang dan atau jasa baik untuk memenuhi kebutuhan sendiri maupun untuk masyrakat. Dari definisi seperti ini, berarti siapa pun pada usia berapa pun yang dapat bekerja untuk menghasilkan barang atau jasa, dapat disebut sebagai tenaga kerja (Adji, dkk 2007). Munir dan Budiarto (1985) dalam bukunya tentang Aspek Demografis Tenaga Kerja mengatakan bahwa angkatan kerja meliputi, orang-orang yag bekerja guna mendapatkan upah atau gaji (dibidang pekerjaan sipil atau angkatan bersenjata), pekerja tanpa buruh dan pengusaha-pengusaha yang bekerja untuk mendapatkan keuntungan, dan termasuk juga anak-anak petani yang membantu bekerja dipertanian tanpa dibayar dalam suatu keluarga yang menghasilkan pendapatan, sebagaimana rekomendasi internasional, definisi tentang orang-orang yang tidak bekerja tetapi sedang mencari pekerjaan dimasukan dalam angkatan kerja. Angkatan kerja merupakan bagian dari tenaga kerja yang aktif dalam kegiatan ekonomi. Aktif ini tidak selalu berarti sudah bekerja karena yang digolongkan sebagai angkatan kerja adalah penduduk dalam usia kerja (15 tahun ke atas) baik yang bekerja maupun yang mencari pekerjaan (pengangguran). Batas usia ini diatur 
dalam UU No. 20 Tahun 1999 Pasal 2 Ayat 2. Sementara itu, menurut versi Bank Dunia adalah antara 15-64 tahun. Menteri Tenaga Kerja Dan Transmigrasi Republik Indonesia (2011) Nilai Ambang Batas yang selanjutnya disingkat NAB adalah standar faktor bahaya ditempat kerja sebagai kadar/intensitas rata-rata tertimbang waktu (time weighted average) yang dapat diterima tenaga kerja tanpa mengakibatkan penyakit atau ganguan kesehatan, dalam pekerjaan sehari-hari untuk waktu tidak melebihi 8 jam sehari atau 40 jam seminggu.

\section{Pengertian Peran}

Kamus Bahasa Indonesia pengertian peran adalah sesuatu yang menciptakan bagian yang memegang pimpinan atau kekuasaan terutama dalam terjadinya suatu hal ataupun peristiwa. Soekanto, (1992) dalam Nurmayasari, (2014) Peran adalah segala sesuatu oleh seseorang atau kelompok orang dalam melakukan sesuatu kegiatan karena kedudukan yang dimilikinya sedangkan menurut Astuti, (2013) Peran adalah keikutsertaan individu atau kelompok dalam suatu kegiatan guna mencapai tujuan individu maupun tujuan bersama. Peran yang terdapat antara pria dan wanita itu tidak dapat ditentukan karena antara keduanya terdapat perbedaan biologis dan kodrat, tetapi dibedakan atau dipilih-pilih menurut kedudukan, fungsi dan peranan masing-masing dalam berbagai bidang kehidupan dan pembangunan.

Sudarta (2003) berkaitan dengan gender diketahui bahwa ada tiga jenis peran gender yaitu peran produktif, peran reproduktif dan peran sosial yang masing-masing peran memiliki pengertian yaitu :

1. Peran produktif adalah peran yang dilakukan oleh seseorang, menyangkut pekerjaan yang menghasilkan barang dan jasa, baik untuk dikonsumsi maupun untuk diperdagangkan. Peran ini sering pula disebut dengan peran di sektor publik.

2. Peran reproduktif adalah peran yang dijalankan oleh seseorang untuk kegiatan yang berkaitan dengan pemeliharaan sumber daya manusia dan pekerjaan urusan rumah tangga, seperti mengasuh anak, memasak, mencuci pakaian dan alat-alat rumah tangga, menyetrika, membersihkan rumah, dan lain-lain. Peran reproduktif ini disebut juga peran di sektor domestik.

3. Peran sosial adalah peran yang dilaksanakan oleh seseorang untuk berpartisipasi di dalam kegiatan sosial kemasyarakatan, seperti gotong-royong dalam menyelesaikan beragam pekerjaan yang menyangkut kepentingan bersama.

\section{Pengertian Peranan Wanita}

Soekanto, 1992 dalam Astuty, 2013 menyebutkan bahwa suatu peranan paling sedikit mencakup tiga hal,yaitu :

a. Peranan meliputi norma-norma yang dihubungkan dengan posisi atau tempat seseorang dalam masyarakat. Peranan dalam arti ini merupakan rangkaian peraturan-peraturan yang membimbing seseorang dalam kehidupan bermasyrakat.

b. Peran adalah suatu konsep perihal apa yang dapat dilakukan individu dalam masyrakat sebagai organisasi.

c. Peran juga dapat dikatakan sebagai perikelakuan individu yang penting bagi struktur sosial masyrakat.

Peran adalah bagian yang dimainkan seseorang pada setiap keadaan dan cara bertingkahlaku untuk menyelaraskan diri dengan keadaan (Tobing, 2009). Dalam hal ini, menurut Sajogyo (1983) dalam Lutfi (2010) peranan perempuan dapat dianalisis dalam dua cara yaitu: Pertama, dalam status atau kedudukannya sebagai ibu rumah tangga, wanita melakukan pekerjaan rumah tangga sebagai bagian dari proses reproduksi yaitu suatu pekerjaan yang tidak langsung menghasilkan pendapatan tetapi memungkinkan anggota rumah tangga yang lain untuk melakukan pekerjaan mencari nafkah. Kedua, pada posisi sebagai pencari nafkah (tambahan atau pokok), wanita melakukan pekerjaan produktif yang langsung menghasilkan pendapatan.

Peranan wanita dalam pembangunan adalah hak dan kewajiban yang dijalankan oleh wanita pada status atau kedudukan tertentu dalam pembangunan, baik pembangunan di bidang politik, ekonomi, sosial budaya maupun 
pembangunan di bidang pertahanan dan keamanan, baik di dalam keluarga maupun di dalam masyarakat (Sudarta, 2003). Peranan wanita dalam pembangunan yang berwawasan gender, berarti peranan wanita dalam pembangunan Sesuai dengan konsep gender peran produktif, peran reproduktif dan peran sosial yang sifatnya dinamis. Dinamis dalam arti, dapat berubah atau diubah sesuai dengan perkembangan keadaan, dapat ditukarkan antara pria dengan wanita dan bisa berbeda lintas budaya (Sajogyo, 1983).

\section{Konsep Gender}

Konsep gender adalah sifat yang melekat pada kaum pria dan wanita yang dibentuk oleh faktor-faktor sosial maupun budaya, sehingga lahir beberapa anggapan tentang peran sosial dan budaya pria dan wanita. Oleh karena itu, dapat dikatakan gender sebagai konsep sosial yang membedakan (dalam arti memisahkan) peran antara laki-laki dan perempuan (Nurmayanti, 2009).

Perbedaan fungsi dan peran antara pria dan wanita itu tidak ditentukan karena antara keduanya terdapat perbedaan biologis dan kodrat, tetapi dibedakan atau dipilih-pilih menurut kedudukan, fungsi dan peranan masing-masing dalam berbagai bidang kehidupan dan pembangunan. Dengan melihat perbedaan yang jelas antara laki-laki dan perempuan, maka dapat dikatakan perbedaan itu terjadi secara kodrati. Fungsi kodrati ini tidak dapat ditukarkan dengan laki-laki (Handayani dan Sugiarti, 2001).

Wiliam (2006) Gender sama sekali berbeda dengan pengertian jenis kelamin. Genderbukan jenis kelamin. Gender bukanlah wanita ataupun pria.Gender hanya memuat perbedaan fungsi dan peran sosial pria dan wanita, yang terbentuk oleh lingkungan tempat kita berada.Gender tercipta melalui proses sosial budaya yang panjang dalam suatulingkup masyarakat tertentu, sehingga dapat berbeda dari satu tempat ketempat lainnya.

\section{Konsep Curahan Waktu Kerja}

Curahan waktu kerja pada usahatani adalah jumlah jam kerja yang dicurahkan anggota rumah tangga pada kegiatan usahatani. Curahan waktu kerja dalam usahatani dibagi menjadi curahan waktu kerja suami dan curahan watu kerja istri. Curahan waktu kerja memiliki pengaruh terhadap pendapatan keluarga petani, dimana keluarga yang mengalokasikan mayoritas waktu kerjannya pada usahatani pasti telah memperhitungkan bahwa pendapatan yang diperoleh dari kegiatan usahatani lebih besar daripada melakukan usaha ekonomi lainnya pada waktu tersebut, sebaliknya jika suatu kegiatan usahatani berpotensi memberikan penghasilan yang cenderung menurun, seperti harga jual produk sedang rendah, maka keluarga petani akan mengalihkan waktu dan tenaganya untuk bekerja dari sumber penghidupan yang lebih baik walaupun hanya sementara atau mengisi waktu.

\section{Tenaga Kerja Wanita dalam Usahatani Hortikultura}

Tenaga kerja dalam usahatani merupakan salah satu unsur penting selain tanah, modal dan manejemen. Tenaga kerja dalam usahatani dibedakan dalam 3 jenis yaitu tenaga kerja manusia, tenaga kerja hewan, dan tenaga kerja mesin/mekanis. Sedangkan tenaga kerja manusia dibedakan menjadi tiga jenis pula yaitu tenaga kerja pria, tenaga kerja wanita dan tenaga kerja anak. Dalam pertanian wanita tidak hanya berperan sebagai ibu rumah tangga saja namun tidak jarang pula ditemukan wanita yang secara langsung memberi sumbangan waktu kerja terhadap suatu usahatani. Sumbangan wanita tani dalam pembangunan pertanian cukup besar. Mereka bekerja dalam beberapa aspek produksi, pasca panen, distribusi pangan dan konsumsi. Mereka tidak saja berperan pada kegiatan pertanian yang bertujuan dalam menambah penghasilan keluarga, namun mereka juga ikut dalam proses pengambilan keputusan (Nurmayanti, 2009).

Berbagai penelitian dalam sektor pertanian menunjukan bahwa peran wanita pada kegiatan pertanian sangat substasial. Kesemuanya menyebut adanya pembagian kerja dimana wanita melakukan kerja selama proses produksi yang meliputi penanaman, penyiangan, pemeliharaan, panen, pasca panen, pemasaran, baik yang bersifat manajerial tenaga buruh, pada komoditi tanaman pangan ataupun tanaman industri yang diekspor.

Setiap usahatani yang diusahakan, kebutuhan tenaga kerja yang diperlukan tentulah 
berbeda dari cabang usahatani satu dengan cabang usahatani yang lainnya. Kebutuhan kerja itu dibuat apabila diketahui urutan pekerjaan yang harus dikerjakan atau dilakukan. Kegiatan-kegiatan pada usahatani hortikultura antara lain :

1. Pembibitan, kegiatan ini meliputi: penyemaian benih dan pemeliharaan persemaian.

2. Pengolahan tanah, kegiatan ini meliputi : mencangkul dan pembuatan bedengan.

3. Penanaman, kegiatan ini meliputi: penanaman bibit pada lahan yang telah disediakan.

4. Penyiangan, kegiatan ini meliputi: mencabut rumput yang tumbuh disekitar tanaman serta perawatan.

5. Pengendalian hama dan penyakit, kegiatan ini meliputi : Penyemprotan pestisida serta pemeliharaan pada tanaman.

6. Pemupukan, kegiatan ini meliputi : pemberian pupuk pada tanaman

7. Panen, kegiatan ini meliputi : pemetikan hasil

\section{Penelitian Terdahulu}

1. Debora Philip, 2013. Judul : Curahan Kerja Wanita Pada Usahatani Padi Sawah Didesa Beha Kecamatan Tabukan Utara Kabupaten Kepulauan Sangihe. Hasil pembahasan curahan kerja wanita dalam usahatani padi sawah didesa beha cukup besar mencapai 35 persen dari total tenaga kerja 64,30 HOK. Pada pekerjaan-pekerjaan dalam usahatani padi sawah keseluruhan terdapat curahan kerja wanita mulai dari persemaian, pengolahan tanah, penanaman, penyiangan, pemupukan, pengendalian hama dan penyakit dan panen/pasca panen. Persentase terbesar curahan waktu kerja wanita pada kegiatan panen yaitu: 5,34 $\mathrm{HOK}$ per $\mathrm{Ha}$, penyiangan 4,22 HOK per Ha dan penanaman yaitu 4,41 hok per Ha. Sedangkan pada pekerjaan-pekerjaan lain melibatkan tenaga kerja wanita dalam keluarga.

2. Vero Stevanus Tampun Worong, 2016. Judul : Partisipasi Tenaga Kerja Wanita Dalam Usahatani Bunga Potong Di Kelurahan Kakaskasen II Kecamatan
Tomohon Utara Kota Tomohon. Dengan hasil pembahasan yaitu (1). Diketahui dalam tahap penjualan tergolong tinggi dalam interprestasinya berdasarkan tingkat partisipasi kehadiran dalam keaktifan pada partisipasi tenaga kerja wanita dalam usaha bunga potong di Kelurahan Kakaskasen II Kecamatan Tomohon Utara Kota Tomohon. (2). Terlihat dari hasil analisis menggunakan skala Likert maka dapat diketahui bahwa angka indeks partisipasi tenaga kerja wanita dalam usaha bunga potong di Kelurahan Kakaskasen II berada pada titik 85,6\% dan tergolong tinggi.

Berdasarkan latar belakang diatas maka penulis tertarik untuk meneliti tentang Peran Tenaga Kerja Wanita Dalam UsahaTani Hortikultura, yang menjadi tempat penelitian adalah Kelurahan Wailan.

\section{Perumusan Masalah}

Bagaimana peran tenaga kerja wanita dalam usahatani hortikultura di Kelurahan Wailan.

\section{Tujuan Penelitian}

Untuk mengetahui peran tenaga kerja wanita dalam usahatani hortikultura di Kelurahan Wailan.

\section{Manfaat Penelitian}

Manfaat dari penelitian ini yaitu sebagai sumber ilmu pengetahuan tentang peran tenaga kerja wanita dalam usahatani hortikultura. Penulisan ini juga diharapkan dapat menjadi bahan studi referensi untuk penulis-penulis selanjutnya dan referensi dalam melaksanakan penelitian serupa.

\section{METODOLOGI PENELITIAN}

\section{Waktu Dan Tempat Penelitian}

Penelitian ini di laksanakan selama empat Bulan yaitu dari Bulan November 2016 sampai April Tahun 2017 mulai dari persiapan sampai penyusunan laporan penelitian. Tempat penelitian adalah di Kelurahan Wailan. 


\section{Metode Penelitian}

Metode yang digunakan dalam penelitian ini yaitu deskriptif kualitatif dengan memilih sampel survey diKelurahan Wailan

\section{Metode pengumpulan data}

Penelitian ini menggunakan data primer dan data sekunder. Data primer diperoleh melalui wawancara langsung pada wanita tani hortikultura tentang pembibitan, pengolahan tanah, penanaman, penyiangan, pengendalian hama dan penyakit, pemupukan dan panen, dengan menggunakan daftar pertanyaan yang telah disiapkan berupa kuisoner, data yang diambil adalah data sesaat tidak untuk 1 musim tanam sedangkan data sekunder diperoleh dari kantor Kelurahan Wailan serta instansi yang terkait dalam penelitian ini.

\section{Metode Pengambilan Sampel}

Populasi dalam penelitian ini yaitu semua wanita tani yang sudah berkeluarga dan bekerja pada usahatani hortikultura. Pengambilan sampel menggunakan metode (purposive sampling), purposive memilih wanita yang masih bersuami dan bekerja pada usahatani hortikultura. Sampel diambil sebantyak 30 responden secara snow ball.

\section{Konsep Pengukuran Variabel}

Adapun variabel yang akan di teliti adalah peran wanita dalam usahatani hortikultura yang diukur dengan curahan waktu kerja wanita dalam setiap jenis kegiatan, kegiatan tersebut meliputi :

1. Pembibitan (jam/hari)

2. Pengolahan tanah (jam/hari)

3. Penanaman (jam/hari)

4. Penyiangan (jam/hari)

5. Pengendalian hama penyakit (jam/hari)

6. Pemupukan (jam/hari)

7. Panen (jam/hari)

\section{Metode Analisis Data}

Metode analisis data yang digunakan dalam penelitian ini adalah analisis deskriptif, dimana data yang terkumpul akan disajikan dalam bentuk tabel.

\section{HASIL DAN PEMBAHASAN}

\section{Deskripsi Lokasi Penelitian}

Kelurahan Wailan memiliki jumlah penduduk 3.199 jiwa yang terdiri dari 1.634 laki-laki dan 1.565 perempuan yang sebagian besar penduduk Kelurahan Wailan bermata pencaharian sebagai petani. Kelurahan wailan memiliki 823 kepala keluarga dan 72,9\% diantaranya memiliki lahan pertanian.

\section{Keadaan Geografis Lokasi Penelitian}

Tomohon adalah salah satu kota di Provinsi Sulawesi Utara dengan Ibukota Kota Tomohon adalah Tomohon, luas Kota Tomohon adalah 147,21 $\mathrm{Km}^{2}$ dengan jarak sekitar $23 \mathrm{Km}$ dari Kota Manado, ibukota Provinsi Sulawesi Utara. Dalam penelitian ini dilaksanakan pada Kelurahan Wailan yang merupakan salah satu Kelurahan yang ada di Kota Tomohon (BPS dalam Angka Tomohon, 2016).

Kelurahan Wailan berada di bagian Utara Kota Tomohon dengan luas wilayah \pm $450 \mathrm{Ha}$.

Batas wilayah administratif Kelurahan Wailan sebagai berikut :
a. Sebelah Utara : Kelurahan Kakaskasen Dua
b. Sebelah Selatan : Kelurahan Woloan dan Kelurahan Kayawu
c. Sebelah Timur : Kelurahan Kakaskasen dan Kelurahan Kakaskasen Tiga
d. Sebelah Barat : Kelurahan Kayawu

Karakteristik Responden
Karakteristik responden dalam
penelitian ini terdiri dari umur, tingkat
pendidikan, jumlah tanggungan dan luas lahan.

\section{Umur}

Umur sangat mempengaruhi kemampuan seseorang baik dalam cara berfikir maupun bekerja. Umur yang produktif adalah pada usia 16 tahun sampai 60 tahun, jika diatas 60 tahun maka usia fisik petani semakin menurun dan produktifitas dalam usahatani makin berkurang. Menurut penelitian yang sudah dilakukan umur responden dapat dilihat pada Tabel 1 . 
Tabel 1. Jumlah Dan Persentase Petani Responden Menurut Kelompok Umur

\begin{tabular}{llll}
\hline No & Umur (Tahun) & Jumlah Responden (Orang) & Persentase (\%) \\
\hline 1 & $26-35$ & 3 & 10 \\
2 & $36-45$ & 9 & 30 \\
3 & $46-55$ & 11 & 36,66 \\
4 & $56-65$ & 6 & 20 \\
5 & $>66$ & 1 & 3,33 \\
\hline Jumlah & & $\mathbf{3 0}$ & $\mathbf{1 0 0}$ \\
\hline
\end{tabular}

Umur adalah salah satu hal yang paling berpengaruh pada seseorang dalam melakukan suatu kegiatan ataupun pekerjan, dalam hal ini pada kegiatan usahatani. Hasil penelitian menunjukan bahwa sebagian besar responden berada pada usia produktif, yaitu usia 46 - 55 sebanyak $36,66 \%$, 30\% berada pada usia 36 - 45 sedangkan pada usia 56 65 tahun berkisar $20 \%$ diikuti $10 \%$ pada usia 26 - 35 tahun dan 3,33\% responden berada pada usia $>66$ tahun.

\section{Tingkat Pendidikan}

Pendidikan sangat penting dalam meningkatkan pendapatan petani dan cara berpikir petani dalam mengurangi biaya dan meningkatkan produksi usahatani. Semakin tinggi tingkat pendidikan seseorang maka semakin muda seorang petani dalam menjalankan usahanya. Berdasarkan hasil penelitian, tingkat pendidikan petani dapat dilihat pada Tabel 2.

Hasil penelitian menunjukan bahwa tingkat pendidikan petani di Kelurahan Wailan, memiliki tingkat pendidikan terbanyak yaitu $60 \%$ pada tingkat pendidikan Sekolah Dasar (SD), sedangkan 36,66\% berada pada tingkat pendidikan SMP dan pada tingkat pendidikan SMA hanya mencapai $3,33 \%$.

\section{Jumlah Tanggungan Responden}

Jumlah tanggungan anggota keluarga merupakan jumlah kebutuhan atau biaya pada setiap anggota keluarga yang ditanggung oleh kepala keluarga.

Tabel 3 menunjukan bahwa jumlah tanggungan keluarga responden antara 2 - 3 yaitu 15 responden dengan persentase $50 \%$ dari total responden dan diikuti pada jumlah tanggungan keluarga antara 4 - 5 yaitu 13 responden dengan persentase $43,33 \%$ sedangkan pada tanggungan $6-7$ yaitu 2 responden dengan persentase $6,66 \%$.

\section{Luas Lahan}

Luas lahan merupakan faktor produksi penting dalam kegiatan usahatani. Keadaan lahan serta luas suatu lahan sangat berpengaruh pada tingat produksi serta peran seorang wanita dalam usahatani yang diusahakan. pada Tabel 4 disajikan data luas lahan petani.

Tabel 4 Menunjukan bahwa sebagian besar responden memiliki luas lahan dengan kisaran < 0,5 Ha yaitu mencapai 16 responden dari total responden dengan persentase $53,33 \%$ sedangkan responden yang memeiliki luas lahan antara $0,5-1,0 \mathrm{Ha}$ berjumlah 14 responden dengan persentase $46,66 \%$.

Tabel 2. Jumlah Dan Presentase Responden Menurut Tingkat Pendidikan

\begin{tabular}{llll}
\hline No & Tingkat Pendidikan & Jumlah Responden (Orang) & Persentase (\%)
\end{tabular}

\begin{tabular}{llll}
\hline 1 & SD & 18 & 60 \\
2 & SMP & 11 & 36,66 \\
3 & SMA & 1 & 3,33 \\
\hline Jumlah & & $\mathbf{3 0}$ & $\mathbf{1 0 0}$ \\
\hline
\end{tabular}


Tabel 3. Jumlah Tanggungan Responden

No Jumlah Tanggungan $\begin{aligned} & \text { Jumlah Responden } \\ & \text { (Orang) }\end{aligned} \quad$ Persentase (\%)

\begin{tabular}{llll}
\hline 1 & $2-3$ & 15 & 50 \\
2 & $4-5$ & 13 & 43,33 \\
3 & $6-7$ & 2 & 6,66 \\
\hline Jumlah & & $\mathbf{3 0}$ & $\mathbf{1 0 0}$ \\
\hline
\end{tabular}

\section{Peran Tenaga Kerja Wanita dalam Usahatani Hortikultura di Kelurahan Wailan}

Tenaga kerja merupakan salah satu faktor paling utama dalam keberhasilan suatu usahatani, baik itu tenaga kerja laki-laki maupun tenaga kerja wanita. Penelitian ini yang dilihat adalah kegiatan yang dilakukan dalam 1 hari kerja untuk beberapa jenis kegiatan usahatani dengan jam kerja dimulai dari pukul $08.00-17.00$ WITA. Peran wanita dalam usahatani hortikultura dapat dilihat pada Tabel 5.

Hasil penelitian menunjukan bahwa dalam setiap kegiatan pada usahatani hortikultura di Kelurahana Wailan mulai dari kegiatan pembibitan, pengolahan tanah, penanaman, penyiangan, pengendalian hama dan penyakit, pemupukan dan panen hanya pada kegiatan pengendalian hama dan penyakit wanita tidak berperan, pada kegiatan yang dilakukan responden dalam 1 hari kerja kegiatan yang dilakukan bukanlah hanya 1 kegiatan saja dalam sehari namun ada yang belakukan 2 kegiatan dalam 1 hari kerja. Setiap kegiatan yang dilakukan dalam usahatani disesuaikan dengan kondisi dan kebutuhan yang ada dikebun. Hal ini menyebabkan pada setiap kegiatan yang terlihat pada Tabel 5 tergolong kecil karena masing-masing responden melakukan kegiatan yang berbeda-beda dalam 1 hari kerja.

\section{Kegiatan Pembibitan}

Kegiatan pembibitan yang dilakukan adalah pencabutan bibit bawang daun. Dalam penelitian ini ingin dilihat bagaimana peran tenaga kerja wanita dalam kegiatan pembibitan dengan melihat jumlah wanita yang ikut bekerja saat kegiatan pembibitan serta jam kerja yang dicurahkan dalam kegiatan tersebut. Tabel 5 menunjukan jumlah dan persentase waktu kerja wanita dalam kegiatan pembibitan.

Hasil penelitian menunjukan bahwa pada kegiatan pembibitan dalam 1 hari kerja, 3,33\% (1 responden) berperan dalam kegiatan pembibitan dengan jumlah waktu kerja adalah 4 jam/hari, 3,33\% (1 responden) berperan dalam kegiatan pembibitan dengan jumlah jam kerja 8 jam/hari sedangakan 93,33\% (28 responden) tidak melakukan kegiatan pembibitan pada saat itu. Dari hasil penelitian bahwa pada kegiatan pembibitan keselurahan responden melakukan kegiatan pembibitan, namun pada saat pengambilan data dalam 1 hari kerja hanya ada 2 responden yang melakukan kegiatan pembibitan sedangkan untuk 28 responden lainnya melakukan kegiatan lain seperti pengolahan tanah, penanaman, penyiangan, pemupukan dan panen.

\section{Kegiatan Pengolahan Tanah}

Kegiatan yang dilakukan dalam pengolahan tanah adalah mencangkul dan pembuatan bedengan-bedengan serta pembuatan lubang untuk menanam sayur kol. Dalam penelitian ini ingin dilihat bagaimana peran tenaga kerja wanita dalam kegiatan pengolahan tanah yaitu dengan melihat jumlah wanita yang ikut bekerja saat kegiatan pembibitan serta jam kerja yang dicurahkan dalam kegiatan pengolahan tanah tersebut. Tabel 5 menunjukan jumlah dan persentase waktu kerja wanita dalam kegiatan pengolahan tanah.

Hasil penelitian menunjukan bahwa dalam kegiatan pengolahan tanah dalam 1 hari kerja wanita yang ikut bekerja dengan jumlah jam kerja 2 jam/hari berjumlah 3 responden dengan persentase $10 \%$, untuk jam kerja 4 
jam/hari berjumlah 9 responden dengan persentase $30 \%$, dan $6,66 \%$ (2 responden) bekerja dengan waktu 6 jam/hari, sedangkan $53,33 \%$ (16 responden) tidak melakukan kegiatan pengolahan tanah. Dari hasil penelitian bahwa pada kegiatan pengolahan tanah keseluruhan responden melakukan kegiatan pengolahan tanah, namun pada saat pengambilan data ini, dalam 1 hari kerja dari keseluruhan responden hanya 14 responden yang melakukan kegiatan pengolahan tanah sedangkan untuk 16 responden lain melakukan kegiatan yang berbeda-beda seperti pembibitan, penanaman, penyiangan, pemupukan dan panen.

\section{Kegiatan Penanaman}

Kegiatan yang dilakukan dalam penanaman adalah proses memindahkan bibit yang telah disemaikan sebelumnya ke tanah yang telah diolah yaitu bedengan-bedengan, kegiatan menimbun tanaman serta kegiatan penyulaman, pada kegiatan ini tanaman yang ditanam adalah bawang daun, sayur pitsai, sayur boncis dan sayur terong.

Dalam penelitian ini ingin dilihat bagaimana peran tenaga kerja wanita dalam kegiatan penanaman yaitu dengan melihat jumlah wanita yang ikut bekerja saat kegiatan penanaman serta jam kerja yang dicurahkan dalam kegiatan penanaman tersebut. Tabel 5 menunjukan jumlah dan persentase waktu kerja wanita dalam kegiatan penanaman. Hasil penelitian menunjukan bahwa pada kegiatan penanaman dalam 1 hari kerja wanita yang berperan dengan jumlah jam kerja 2 jam/hari yaitu $16,66 \%$ (5 responden), 23,33\% (7 responden) bekerja dalam penanaman dengan jumlah jam kerja 4 jam/hari, $6,66 \%$ ( 2 responden) bekerja dengan jumlah waktu kerja 5 jam/hari, 3,33\% (1 responden) bekerja dengan jam kerja 6 jam/hari sedangkan 50\% (15 responden) tidak melakukan kegiatan penanaman. Dari hasil penelitian bahwa keseluruhan responden melakukan kegiatan penanaman, namun pada saat pengambilan data pada 1 hari kerja, responden yang melakukan kegiatan penanaman berjumlah 15 responden sedangkan untuk 15 responden lainnya melakukan kegiatan yang berbeda-beda seperti kegiatan pembibitan, pengolahan tanah, penyiangan, pemupukan dan panen.

\section{Kegiatan Penyiangan}

Kegiatan yang dilakukan dalam penyiangan adalah proses pembersihan tanaman dari gulma, serta proses pencabutan tiang-tiang yang menjadi penyanggah pada tanaman boncis.
Dalam penelitian ini ingin dilihat bagaimana peran tenaga kerja wanita dalam kegiatan penyiangan yaitu dengan melihat jumlah wanita yang ikut bekerja saat kegiatan penanaman serta jam kerja yang dicurahkan dalam kegiatan penyiangan tersebut. Tabel 5 menunjukan jumlah dan persentase waktu kerja wanita dalam kegiatan penyiangan

Hasil penelitian ini menunjukan bahwa pada kegiatan penyiangan dalam 1 hari kerja, wanita yang berperan dengan jumlah jam kerja 2 jam/hari berjumlah 3 responden dengan persentase $10, \%$ dan wanita yang berperan dengan jumlah jam kerja 4 jam/hari berjumlah 2 responden dengan persentase $6,66 \%$ sedangkan pada persentase $86,66 \%$ (25 responden) tidak melakukan kegiatan penyiangan. Dari hasil penelitian bahwa pada kegiatan penyiangan wanita di Kelurahan Wailan melakukan kegiatan penyiangan. Dari hasil penelitian bahwa pada kegiatan penyiangan keseluruhan responden melakukan kegiatan penyiangan, namun pada saat pengambilan data ini dalam 1 hari kerja responden yang melakukan kegiatan penyiangan berjumlah 4 responden sedangkan 26 lainnya melakukan kegiatan lain seperti pembibitan, pengolahan tanh, penanaman, pemupukan dan panen.

\section{Kegiatan Pengendalian Hama dan Penyakit}

Kegiatan yang dilakukan dalam pengendalian hama dan penyakit adalah penyemprotan pestisida pada tanaman. Dalam penelitian ini ingin dilihat bagaimana peran tenaga kerja wanita dalam kegiatan pengendalian hama dan penyakit yaitu dengan melihat jumlah wanita yang ikut bekerja saat kegiatan penanaman serta jam kerja yang dicurahkan dalam kegiatan pengendalian hama dan penyakit. Tabel 5 menunjukan jumlah dan persentase waktu kerja wanita dalam kegiatan pengendalian hama dan penyakit.

Hasil penelitian menunjukan bahwa dalam 1 hari kerja wanita, pada kegiatan pengendalian hama dan penyakit, tidak ada wanita yang ikut berperan atau memberikan curahan waktu kerjanya pada kegiatan pengendalian hama dan penyakit. Pada kegiatan pengendalian hama dan penyakit di Kelurahan Wailan memang sudah menjadi tradisi bahwa pada kegiatan ini hanya dilakukan oleh pria. 
Tabel 4 Luas Lahan Responden

\begin{tabular}{llll}
\hline No & Luas Lahan (Ha) & Jumlah Responden (Orang) & Persentase (\%) \\
\hline 1 & $<0,5$ & 16 & 53,33 \\
2 & $0,5-1,0$ & 14 & 46,66 \\
\hline Jumlah & & $\mathbf{3 0}$ & $\mathbf{1 0 0}$ \\
\hline
\end{tabular}

Tabel 5. Jam Kerja Wanita dalam Usahatani Hortikultura

\begin{tabular}{|c|c|c|c|c|}
\hline No & Jenis Pekerjaan & Jumlah Responden & Jumlah Jam & $\begin{array}{l}\text { Persentase } \\
(\%)\end{array}$ \\
\hline \multirow[t]{3}{*}{1} & Pembibitan & 1 & 4 & 3,33 \\
\hline & Pembibitan & 1 & 8 & 3,33 \\
\hline & Pembibitan & 28 & 0 & 93,33 \\
\hline \multirow[t]{4}{*}{2} & Pengolahan tanah & 3 & 2 & 10 \\
\hline & Pengolahan tanah & 9 & 4 & 30 \\
\hline & Pengolahan tanah & 2 & 6 & 6,66 \\
\hline & Pengolahan tanah & 16 & 0 & 53,33 \\
\hline \multirow[t]{5}{*}{3} & Penanaman & 5 & 2 & 16,66 \\
\hline & Penanaman & 7 & 4 & 23,33 \\
\hline & Penanaman & 2 & 5 & 6,66 \\
\hline & penanaman & 1 & 6 & 3,33 \\
\hline & Penanaman & 15 & 0 & 50 \\
\hline \multirow[t]{3}{*}{4} & Penyiangan & 3 & 2 & 10 \\
\hline & Penyiangan & 2 & 4 & 6,66 \\
\hline & Penyiangan & 25 & 0 & 83,33 \\
\hline 5 & $\begin{array}{l}\text { Pengendalian hama } \\
\text { dan penyakit }\end{array}$ & 30 & 0 & 100 \\
\hline \multirow{3}{*}{6} & Pemupukan & 2 & 2 & 13,33 \\
\hline & pemupukan & 1 & 6 & 3,33 \\
\hline & Pemupukan & 27 & 0 & 90 \\
\hline \multirow[t]{5}{*}{7} & Panen & 2 & 3 & 6,66 \\
\hline & Panen & 4 & 4 & 13,33 \\
\hline & Panen & 4 & 6 & 13,33 \\
\hline & Panen & 5 & 8 & 16,66 \\
\hline & Panen & 15 & 0 & 50 \\
\hline
\end{tabular}

\section{Kegiatan Pemupukan}

Kegiatan yang dilakukan dalam pemupukan adalah pemberian pukuk pada tanah yang telah diolah. Dalam penelitian ini ingin dilihat bagaimana peran tenaga kerja wanita dalam kegiatan pemupukan yaitu dengan melihat jumlah wanita yang ikut bekerja saat kegiatan pemupukan serta jam kerja yang dicurahkan dalam kegiatan pemupukan tersebut..

Kegiatan pemupukan dalam 1 hari kerja wanita yang berperan dengan jumlah 
jam kerja 2 jam /hari berjumlah 2 responden dengan persentase $6,66 \%, 3,33 \% \quad(1$ responden) bekerja dengan jumlah waktu kerja 6 jam/hari sedangkan 90\% (27 responden) tidak melakukan kegiatan pemupukan. Dari hasil penelitian bahwa pada kegiatan pemupukan keseluruhan responden melakukan kegiatan pemupukan namun pada saat pengambilan data ini dalam1 hari kerja hanya 4 responden yang melakukan kegiatan pemupukan sedangkan untuk 26 responden lainnya dihari yang sama melakukan kegiatan lain seperti kegiatan pembibitan, peengolahan tanah, penanaman, penyiangan, dan panen.

\section{Kegiatan Panen}

Tabel 5 menunjukan jumlah dan persentase waktu kerja wanita dalam kegiatan panen. Dalam penelitian ini ingin dilihat bagaimana peran tenaga kerja wanita dalam kegiatan panen yaitu dengan melihat jumlah wanita yang ikut bekerja saat kegiatan panen serta jam kerja yang dicurahkan dalam kegiatan panen.

Hasil penelitian menunjukan bahwa dalam 1 hari kerja, wanita yang berperan dalam kegiatan panen dengan jumlah jam kerja 3 jam/hari berjumlah 2 responden dengan persentase $6,66 \%, \quad 13,33 \% \quad$ (4 responden) bekerja dengan jumlah jam kerja 4 jam/hari, $13,33 \%$ (4 responden) bekerja dengan jumlah jam 6 jam/hari, 16,66\% (5 responden) bekerja dengan jumlah jam kerja 8 jam/hari sedangkan 50\% (15 responden) tidak melakukan kegiatan panen. Dari hasil penelitian pada kegiatan panen semua responden melakukan kegiatan panen namun pada saat pengambilan data ini dalam 1 hari kerja hanya 15 responden yang melakukan kegiatan panen sedangkan 15 responden lainnya pada hari yang sama melakukan kegiatan lain seperti pembibitan, pengolahan tanah, penanaman, penyiangan dan pemupukan. Kegiatan yang dilakukan dalam memanen adalah pemotongan sayuran pitsai dan caisim, pencabutan bawang daun, memetik sayur buncis dan memetik cabai.

Pada Gambar 1 dapat di ketahui bahwa rata-rata jam kerja wanita pada kegiatan pembibitan $0,4 \mathrm{jam} / \mathrm{hari}$, pengolahan tanah $1,66 \mathrm{jam} / \mathrm{hari}$, penanaman $1,7 \mathrm{jam} / \mathrm{hari}$, penyiangan $0,46 \mathrm{jam} / \mathrm{hari}$, pengendalian hama dan penyakit $0 \mathrm{jam} / \mathrm{hari}$, pemupukan $0,26 \mathrm{jam} / \mathrm{hari}$, dan pada kegiatan panen 2,56 jam/hari. Sehingga total keseluruhan jam kerja yang dilakukan oleh wanita dalam usahatani hortikultura berjumlah 7,03 jam/hari. Oleh sebab itu dari hasil penelitian ini dapat diketahui bahwa curahan waktu terbanyak dalam 1 hari kerja terdapat pada kegiatan panen, penanaman, pengolahan tanah, penyiangan, pembibitan dan yang terahkir pada kegiatan pemupukan.

\section{Rata-rata Jam Kerja Wanita dalam 1 Hari Kerja pada Setiap Kegiatan dalam Usahatani Hortikultura}

\begin{tabular}{|c|c|}
\hline \multicolumn{2}{|c|}{ Rata-rata Jam Kerja dalam 1 Hari } \\
\hline Kerja & Pebibitan \\
\hline 0,4 & - Pengolahan Tanah \\
\hline & Penanaman \\
\hline & Penyiangan \\
\hline $0,2600,46$ & $\begin{array}{l}\text { Pengendalian Hama } \\
\text { dan Penyakit } \\
\text { Pemupukan }\end{array}$ \\
\hline
\end{tabular}

Gambar 1. Jam Kerja Wanita Dalam 1 Hari Kerja Pada Usahatani Hortikultura 


\section{Kegiatan Wanita di luar Usahatani}

Sebagai seorang ibu rumah tangga wanita tidak terlepas dari kewajiban dan tanggung jawab yang wajib dilakukan yaitu dalam pekerjaan mengurus rumah tangga, seperti memasak, membersihkan rumah dan mengurus anak.

Dalam penelitian ini jam kerja wanita diluar usahatani dimulai dari jam 05.00-07.00 WITA kegiatan yang mereka lakukan yaitu memasak, mengurus anak, membersihkan rumah, dan mencuci dengan rata-rata jam kerja berjumlah 1,9 jam/ hari dari 30 responden. Sedangkan kegiatan wanita diluar usahatani pada sore hari dimulai dari jam 17.30-18.00 kegiatan yang mereka lakukan yaitu memasak dengan rata-rata jam kerja 0.30 jam/hari

\section{KESIMPULAN DAN SARAN}

\section{Kesimpulan}

Hasil penelitian menunjukan bahwa peran wanita dalam usahatani hortikultura di Kelurahan Wailan ditunjukan dengan jumlah jam kerja yang dicurahkan pada usahatani ratarata per kegiatan yaitu panen 2,56 jam/hari, penanaman $1,7 \mathrm{jam} / \mathrm{hari}$, pengolahan tanah 1,66 jam/hari, penyiangan 0,46 jam/hari, pembibitan 0,4 jam/hari, pemupukan $0,26 \mathrm{jam} / \mathrm{hari}$ dan pengendalian hama dan penyakit $0 \mathrm{jam} / \mathrm{hari}$.

\section{Saran}

Diharapkan pada kegiatan pengendalian hama dan penyakit tidak hanya dilakukan oleh pria saja tetapi wanita juga ikut berperan dalam pengelolaan keuangan rumah tangga diharapkan lebih efisien agar kehidupan keluarga lebih baik.

\section{DAFTAR PUSTAKA}

Adji, dkk. 2007. Ekonomi Untuk Sma/Ma Jilid 2. Penerbit Erlangga. Jakarta.

Astuti, W.W.A., 2013. Peran Ibu Rumah Tangga Dalam Meningkatkan Kesejahteraan Keluarga. Fakultas Ilmu Pendidikan Universitas Negri Semarang. Skripsi. Semarang.
Ginting, T. 2015. Dampak Terapan Media Komunikasi Pada Usahatani Hortikultura Dikelurahan Rurukan. Fakultas Pertanian Universitas Sam Ratulangi. Skripsi. Manado

Handayani, T dan Sugiarti. 2001. Konsep Dan Teknik Penelitian Gender. Pusat Studi Wanita Dan Masyarakat Universitas Muhammadiyah. Malang

Iskandar, M. 2011. Mentri Tenaga Kerja Dan Transmigrasi Republik Indonesia, Jakarta.

Luthfi, A.2010.Akses Dan Kontrol Perempuan Petani Penggarap Pada Lahan Pertanian PTPN IX Kebun Merbuh. Jurusan Sosiologi Dan Antropologi, Fakultas Ilmu Sosial, Universitas Negeri Semarang, Indonesia. Jurnal. Semarang

Mifta, F.D., 2000. Kontribusi Tenaga Kerja Pada Usahatani Kopi Di Desa Purworejo Dan Kecamatan Modayag. Universitas Samratulangi Fakultas Pertanian. Skripsi. Manado

Munir, R. dan Budiarto. 1985. Aspek Demografis Tenaga Kerja. Penerbit AKADEMIKA PRESINDO. Jakarta

Novita, R. 2012.Faktor-Faktor Yang Mempengaruhi Curahan WaktuKerja Wanita Tani Pada Usahatani Padi Sawah(Studi Kasus Di Desa Ngarjo Kecamatan MojoanyarKabupaten Mojokerto). Universitas Briwijaya. Malang.

Nurmayanti, 2009. Peran Perempuan Dalam Program Pembangunan Pertanian. Fakultas Ekologi Manusia. IPB. Bogor.

Nurmayasari, D. 2014. Peran Anggota Wanita Tani Laras Asri Pada Peningkatan Kesejahteraan Keluarga. Fakultas Ilmu Pendidikan Universitas Negri Semarang Indonesia

Pelealu, S. 2005. Produktifitas Tenaga Kerja Pada Usahatani Seledri Di Kelurahan Luaan Kecamatan Tondano Timur. Fakultas Pertanian Universitas Sam Ratulangi. Skripsi. Manado 
Sajogyo, P. 1983. Peranan Wanita Dalam Perkembangan Masyarakat Desa. Rajawali

Soekartawi, 1995. Analisis usahatani. Penerbit Universitas Indonesia. Jakarta

Sudarta, W. 2003. Peranan Wanita Dalam Pembangunan Berwawasan Gender. Jurnal Studi Jender SRIKANDI.

Tobing, E.J.,E. 2009. Peranan Tenaga Kerja Wanita Pada Usahatani Kopi Dan Sikapnya Terhadap Peran Ganda Dalam Rumah Tangga. Fakultas Pertanian. Universitas Sumatera Utara. Skripsi. Medan
Tohir, A.K, 1991. Seuntai Pengetahuan Usahatani Indonesia. PT RINEKE CIPTA. Jakarta

Wijaya, K.M., 2012. Pengantar Agronomi Sayuran. Prestasi Pustaka

Wiliam, D. 2006. Gender Bukan Tabu. Center ForIinternasional Forestry Researc. Jakarta

Zulkarnain, 2014. Dasar-Dasar Hortikultura. PT Bumi Aksara. Jakarta 